\title{
Marked Delay in \\ Excystment of Schizopyrenus russelli Cysts by $p$-Chloromercuric Benzoate and its Reversal with Reduced Glutathione
}

\author{
By A. K. RASTOGI, P. SAGAR And S. C. AGARWALA \\ Central Drug Research Institute, Lucknow, India \\ (Accepted for publication 5 February 1969) \\ SUMMARY \\ $p$-Chloromercuric benzoate ( $p$-CMB) caused marked delay in excystment \\ of Schizopyrenus russelli cysts when incorporated in the aqueous extract of \\ Escherichia coli, an excystment agent. Cysts treated with $p$-CMB first and \\ then with reduced glutathione (GSH), excysted readily in the presence of \\ bacterial extract, after the removal of $p$-CMB and GSH.
}

\section{INTRODUCTION}

Actively proliferating bacteria of an Aerobacter sp. and Escherichia coli and their aqueous extracts cause excystment of cysts of Schizopyrenus russelli; certain pure amino acids, within a suitable $\mathrm{pH}$ range, also cause excystment (Singh, Mathew \& Anand, 1958). Further, the excystment-inducing property of glutamic acid and of aqueous extract of $E$. coli was completely inhibited by emetine hydrochloride. This inhibition was completely annulled after the removal of emetine (Imam, Dutta \& Agarwala, I968).

The present communication deals with the delay in excystment of Schizopyrenus russelli cysts caused by $p$-chloromercuric benzoate and its reversal with reduced glutathione.

\section{METHODS}

Preparation of viable sterile cysts of Schizopyrenus russelli. The cysts from a "pure line' culture of the amoeba, growing with Escherichia coli, were used. Cysts free from living and dead bacteria were obtained essentially according to the method of Singh, Saxena \& Iyer (1965). Non-nutrient agar, containing agar 3.5 and $\mathrm{NaCl} 0.5(\% \mathrm{w} / \mathrm{v})$, $\mathrm{pH} 6.8$ to $7 \cdot 0$, in $\mathrm{I} 1$ Roux-type culture flasks was seeded with cysts $\left(\mathrm{I} \times 1 \mathrm{I}^{6}\right)$ and a thick suspension of $E$. coli in $0.5 \%$ (w/v) NaCl. After 12 to I 5 days, at $25^{\circ}$, the cysts were harvested and washed with distilled water several times by centrifugation to get rid of most of the bacteria. They were then treated with $\mathrm{N}-\mathrm{HCl}$ for $24 \mathrm{hr}$ at room temperature to kill bacteria, active amoebae and partially formed cysts. The acid was removed by repeated washing with water. The thick suspension of cysts thus obtained was treated for a few minutes with a sterile solution of trypsin $(2 \%, w / v)$ to lyse dead bacteria completely. The cysts were washed quickly several times with distilled water to get rid of small particles and water-soluble products released from the dead bacteria. After testing the bacterial sterility of the cysts, they were diluted to $10 \times 10^{6} / \mathrm{ml}$, counted with a haemocytometer. 
Bacterial extract. Eighteen hours growth of Escherichia coli on nutrient agar $(\mathrm{NaCl} 0.5 \%$, peptone $\mathrm{I} \%$, Marmite $0.1 \%$ and Lab-Lemco $0.3 \%, \mathrm{pH} 7.2$ ) was harvested with physiological saline and washed twice by centrifugation. The pellet was weighed and, for every g. wet bacteria, $5 \mathrm{ml}$. of distilled water were added. The suspension was autoclaved at $\mathrm{I} 2 \mathrm{I}^{\circ}$ for $\mathrm{I} 5 \mathrm{~min}$., thereafter it was centrifuged aseptically. The clear straw-coloured supernatant fluid $(\mathrm{pH} \mathrm{6.5)}$ was stored in a refrigerator and used as the excystment agent.

Excystment procedure. To $0.1 \mathrm{ml}$. of cyst suspension in a sterile culture tube (IO $\times$ $1.2 \mathrm{~cm}$.) were added $0.7 \mathrm{ml}$. of bacterial extract, followed by $0.1 \mathrm{ml} . p$-CMB solution + $0 . \mathrm{I} \mathrm{ml}$. water in experimental and $0.2 \mathrm{ml}$. distilled water in control experiment. The tubes were incubated in inclined position at $25^{\circ}$. Samples were taken at regular intervals and counts of the different stages of excystment were made with a haemocytometer. Schizopyrenus russelli forms a double-walled cyst and excystment takes place in two stages. First, the inner wall disappears and a small amoeba moves freely within the outer wall. In a successful case, the outer wall gives way and the amoeba emerges.

In pretreatment experiments the same quantity of cysts were incubated with $0 \cdot 1 \mathrm{ml}$. of $p$-CMB solution and/or $0 \cdot \mathrm{I} \mathrm{ml}$. reduced glutathione (final volume $\mathrm{I} \mathrm{ml}$.) for $\mathrm{I} \mathrm{hr}$, after which cysts were washed 3 times with distilled $\mathrm{H}_{2} \mathrm{O}$ and then studied for excystment in bacterial extract, as given earlier. Proper controls were run in all the experiments.

\section{RESULTS}

The data presented in Table $\mathrm{I}$ showed that $p$-CMB, at $10^{-3} \mathrm{M}$ and $5 \times 10^{-3} \mathrm{M}$, completely prevented the emergence of trophozoites from the cysts up to $6 \mathrm{hr}$. At $\mathrm{IO}^{-4} \mathrm{M}$ the excystment in 4 and $6 \mathrm{hr}$ was decreased. At $6 \mathrm{hr}$ in the tubes with $10^{-4} \mathrm{M} p-\mathrm{CMB}$,

Table I. Effect of p-chloromercuric benzoate $(M)$ on the excystment of Schizopyrenus russelli cysts

\begin{tabular}{|c|c|c|c|c|c|c|c|c|c|}
\hline \multirow[b]{2}{*}{ Stage: } & \multicolumn{3}{|c|}{$2 \mathrm{hr}$} & \multicolumn{3}{|c|}{$4 \mathrm{hr}$} & \multicolumn{3}{|c|}{$6 \mathrm{hr}$} \\
\hline & $\mathrm{A}^{*}$ & $\mathrm{~B}^{*}$ & $\mathrm{C}^{*}$ & A & $\mathbf{B}$ & $\mathrm{C}$ & A & B & $\mathrm{C}$ \\
\hline Concn. (M) & \multicolumn{9}{|c|}{ Count $(\%)$} \\
\hline Control & 43 & 19 & 38 & 15 & 22 & 63 & IO & 25 & 65 \\
\hline $5 \times 10^{-3}$ & 95 & 5 & 0 & 91 & 9 & 0 & 86 & 14 & 0 \\
\hline $10^{-3}$ & 90 & 10 & 0 & 89 & I I & 0 & 82 & 18 & 0 \\
\hline $10^{-4}$ & 36 & 54 & IO & 9 & 82 & 9 & 14 & 60 & 26 \\
\hline
\end{tabular}

* A, Intact cysts; B, intermediary stage (trophozoite moving within the outer cyst wall); C, trophozoites.

$60 \%$ of the cysts were in the intermediary stage of excystment, but at higher concentrations of $p-\mathrm{CMB}$ there was a considerable delay in the appearance of intermediary stages and only $\mathrm{I} 4$ to I $8 \%$ cysts were in that stage. Table 2 shows that $8 \mathrm{I} \%$ of cysts pretreated with $p$-CMB $\left(\mathrm{IO}^{-3} \mathrm{M}\right)$ for $\mathrm{I}$ hr were in the intermediary stage of excystment after $4 \mathrm{hr}$ which increased to $93 \%$ in $8 \mathrm{hr}$; but the trophozoites failed to hatch. $p$-CMB at $10^{-4} \mathrm{M}$, which decreased excystment when present throughout the experiment, had no permanent effect since excystment paralleled the control when p-CMB was removed. 
Although $p$-CMB at $10^{-3} \mathrm{M}$ and $5 \times 10^{-3} \mathrm{M}$ completely prevented the emergence of trophozoites from the cysts up to 6 to $8 \mathrm{hr}$, nearly all the cysts excysted in 18 to $24 \mathrm{hr}$, as in the control. Hence all the cysts were viable. The data presented in Table 3 show that, when cysts were treated with $p$-CMB and reduced glutathione (GSH) together, there was $90 \%$ excystment in $4 \mathrm{hr}$, as compared with none when incubated with $p$-CMB alone. There was $76 \%$ excystment in $4 \mathrm{hr}$ when the cysts were first treated with $p$-CMB for $\mathrm{I} \mathrm{hr}$ and then with GSH for $\mathrm{I} \mathrm{hr}$, as against $8 \mathrm{I} \%$ in the control.

Table 2. Effect of pretreatment of cysts of Schizopyrenus russelli with p-chloromercuric benzoate on their subsequent excystment

The cysts were treated with $p$-chloromercuric benzoate for $\mathrm{I} \mathrm{hr}$, washed thrice with distilled water and then left for excystment.

\begin{tabular}{|c|c|c|c|c|c|c|c|c|c|c|c|c|}
\hline \multirow[b]{2}{*}{ Stage: } & \multicolumn{3}{|c|}{$2 \mathrm{hr}$} & \multicolumn{3}{|c|}{$4 \mathrm{hr}$} & \multicolumn{3}{|c|}{$6 \mathrm{hr}$} & \multicolumn{3}{|c|}{$8 \mathrm{hr}$} \\
\hline & $A^{*}$ & $\mathrm{~B}^{*}$ & $C^{*}$ & A & $\mathbf{B}$ & C & A & B & C & A & B & $\mathrm{C}$ \\
\hline Conen. (M) & \multicolumn{12}{|c|}{ Count $(\%)$} \\
\hline Control & 60 & 8 & 32 & 13 & $2 \mathrm{I}$ & 66 & 2 & 8 & 90 & I & 4 & 95 \\
\hline $10^{-3}$ & 65 & 35 & 0 & 19 & $8 I$ & 0 & I6 & 84 & 0 & 7 & 93 & 0 \\
\hline $10^{-4}$ & 72 & 4 & 24 & 34 & 7 & 59 & 6 & 3 & 9 I & 4 & 0 & 96 \\
\hline
\end{tabular}

Table 3. Effect of reduced glutathione in reversing the delay in excystment of Schizopyrenus russelli cysts caused by p-CMB

The cysts after each treatment were washed thrice with distilled water and then put for excystment.

\begin{tabular}{|c|c|c|c|c|c|c|}
\hline \multirow[b]{2}{*}{ Stage: } & \multicolumn{3}{|c|}{$2 \mathrm{hr}$} & \multicolumn{3}{|c|}{$4 \mathrm{hr}$} \\
\hline & $A^{*}$ & $\mathbf{B}^{*}$ & $\mathrm{C}^{*}$ & A & B & C \\
\hline Concn. (м) & \multicolumn{6}{|c|}{ Count $(\%)$} \\
\hline Control & 34 & 4 & 62 & I4 & 5 & $8 \mathrm{I}$ \\
\hline $\begin{array}{l}\text { Pretreated with } p \text {-CMB } \\
\text { for } \mathrm{I} \mathrm{hr}\left(10^{-3} \mathrm{M}\right)\end{array}$ & 95 & 5 & 0 & 47 & 53 & o \\
\hline $\begin{array}{l}\text { Pretreated with } p \text {-CMB } \\
\left(\mathrm{IO}^{-3} \mathrm{M}\right)+\mathrm{GSH}\left(2 \times 1 \mathrm{O}^{-3} \mathrm{M}\right) \\
\text { for } \mathrm{I} \mathrm{hr}\end{array}$ & 13 & o & 87 & 10 & $\circ$ & 90 \\
\hline $\begin{array}{l}\text { Pretreated with } p \text {-CMB } \\
\left(\mathrm{IO}^{-3} \mathrm{M}\right) \text { for } \mathrm{I} \mathrm{hr} \text { and then with } \\
\text { GSH }\left(2 \times 1 \mathrm{O}^{-3} \mathrm{M}\right) \text { for } \mathrm{I} \mathrm{hr} \text {. }\end{array}$ & $\begin{array}{r}45 \\
\quad *\end{array}$ & $\mathrm{C}$ as & ble $\mathrm{I}$. & 24 & o & 76 \\
\hline \multicolumn{7}{|c|}{ DISCUSSION } \\
\hline
\end{tabular}


Authors' thanks are due to Dr N. B. Singh, Scientist in charge of the Microbiology Division, for his keen interest and to Shri R. K. Vaish and Shri R. B. Lal for their technical assistance in these investigations.

C.D.R.I. publication no. $\mathrm{r} 32 \mathrm{r}$.

\section{REFERENCES}

Imam, S. A., DutTa, G. P. \& Agarwal.A, S. C. (I968). Inhibition of excystment of Schizopyrenus russelli cysts in the presence of emetine and its cysticidal effect in conjunction with sodium lauryl sulphate. J. gen. Microbiol. 5I, I7.

Singh, B. N., Mathew, M. \& ANand, N. (1958). The role of Aerobacter sp., Escherichia coli, and certain amino acids in the excystment of Schizopyrenus russelli. J. gen. Microbiol. 19, 104.

Singh, B. N., Saxena, U. \& Iyer, S. S. (1965). Production of viable sterile cysts of free-living amoebae and the role of bacteria on excystment. J. exp. Biol. 3, I Io.

WebB, J. L. (1966). Sulf hydryl Reagents, in Enzyme and Metabolic Inhibitors vol. 2, p. 635. New York: Academic Press. 